
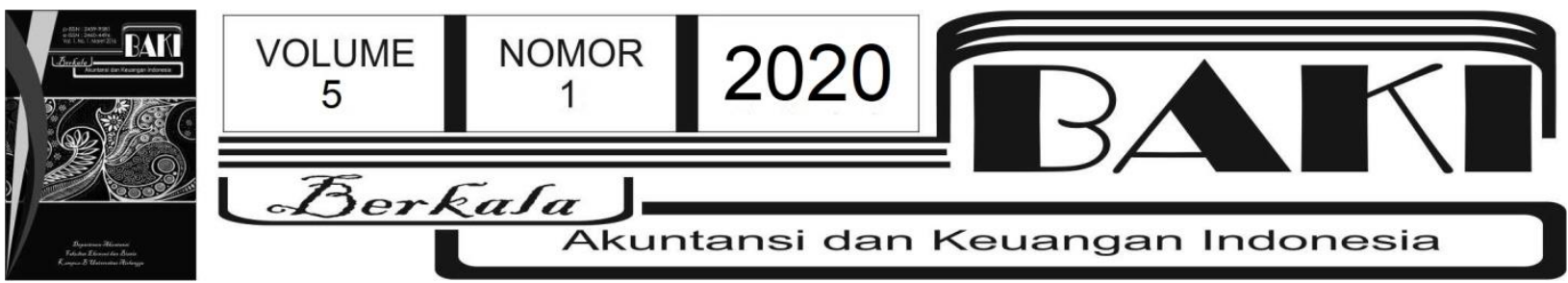

\title{
FAKTOR - FAKTOR YANG MEMPENGARUHI STRUKTUR MODAL PADA PERUSAHAAN MAKANAN DAN MINUMAN DI BEI
}

\author{
Rani Milansari ${ }^{1 a}$ \\ Endang Masitoh ${ }^{1}$ \\ Purnama Siddi ${ }^{1}$
}

${ }^{1}$ Program Studi Akuntansi, Universitas Islam Batik Surakarta (UNIBA) Surakarta

acorresponding author:rmilansari@gmail.com/ Telp: +6285728751527

\section{INFO ARTIKEL}

Histori Artikel:

Tanggal Masuk 7 Januari

2020

Tanggal Diterima 30 Maret 2020

Tersedia Online 15 Mei 2020

Keywords:

CR, ROA, Asset Structure, Capital Structure

\section{A B STRACT}

Capital structure is related with company funding. This study aims to examine the factors influencing the capital structure of food and beverage companies listed in Indonesian Stock Exchange in 20152018. The population is 26 companies and purposive sampling is used to obtain samples of 40 companies. The data is analyzed using multiple linear regression. The results showed that the company's current ratio and size have an effect on the capital structure, meanwhile the return on assets, asset structure and sales growth have no effect. The findings are expected to be useful for management as a material consideration in determining the source of company funding.
Kata Kunci:

CR, ROA, Struktur aset, Struktur Modal

\section{A B S TR AK}

Struktur Modal merupakan sesuatu hal yang berkaitan dengan pendanaan perusahaan. Penelitian ini bertujuan untuk menguji dan menganalisis faktor - faktor yang mempengaruhi struktur modal pada perusahaan makanan dan minuman yang terdaftar di Bursa Efek Indonesia periode 2015-2018. Populasi dalam penelitian ini berjumlah 26 perusahaan dan diporeleh sampel 40 perusahaan menggunakan teknik purposive sampling. Analisis data yang digunakan adalah anaisis regresi linear berganda. Hasil penelitian menunjukkan bahwa current ratio dan ukuran perusahaan berpengaruh terhadap struktur modal, sedangkan return on asset, struktur aset dan pertumbuhan penjualan tidak berpengaruh terhadap struktur modal. Hasil penelitian diharapkan dapat digunakan sebagai bahan pertimbangan pihak manajemen dalam menentukan sumber pendanaan perusahaan.

Berkala Akuntansi dan Keuangan Indonesia p-ISSN: 2459-9581; e-ISSN 2460-4496

DOI: 10.20473/baki.v5i1.17179

Open access under Creative Common Attribution-Non Commercial-Share A like 4.0 International Licence (CC-BY-NC-SA) @(1) @() 


\section{Pendahuluan}

Dalam era globalisasi, perusahaan harus dapat mengevaluasi mengenai kinerjanya, serta dapat melakukan perbaikan agar perusahaan bisa bertumbuh dan bersaing dengan yang lain. Perbaikan kinerja perusahaan mendorong perusahaan menjadi lebih baik, unggul serta bertahan di era persaingan globalisasi ini. Setiap perusahaan mempunyai tujuan yang sama yaitu menghasilkan laba yang optimal agar dapat menjaga kelangsungan hidup perusahaan dalam mengembangkan usahanya. Untuk itu perusahaan mempunyai rencana yang strategis dengan taktik yang disusun dalam rangka pencapaian tujuan yang telah ditetapkan. Menurut Effendi dan Nugraha (2018) menunjukkan bahwa Return On Asset berpengaruh negatif terhadap Struktur Modal. Wardiansyah (2016) menunjukkkan bahwa Return On Asset tidak berpengaruh terhadap Struktur Modal. Lina dan Afriza (2018) menunjukkan bahwa Return On Asset berpengaruh terhadap Struktur Modal. Penelitian Said dan Jusmansyah (2019) menunjukkan bahwa Current Ratio berpengaruh negatif terhadap Struktur Modal. Penelitian Ghasemi dan Razak (2016) menunjukkan bahwa Current Ratio berpengaruh negatif terhadap Struktur Modal. Peneliti Naray dan Mananeke (2015) menunjukkan bahwa Ukuran Perusahaan memiliki pengaruh negatif terhadap struktur modal. Denziana dan Yunggo (2017) menunjukkan bahwa Ukuran Perusahaan memiliki pengaruh positif terhadap Struktur Modal.

Jusrizal (2017) dalam penelitiannya menunjukkan bahwa Struktur Aset berpengaruh terhadap Struktur Modal. Peneliti Septiani dan Suaryana (2018) menunjukkan bahwa Struktur Aset berpengaruh postif terhadap Struktur Modal. Peneliti Ratri dan Christianti (2017) menunjukkan bahwa Pertumbuhan Penjualan berpengaruh negatif terhadap Struktur Modal. Peneliti Hartati dan Mukhibad (2018) menunjukkan bahwa Pertumbuhan Penjualan tidak berpengaruh terhadap Struktur Modal. Berdasarkan gap research diatas, penelitian tersebut menunjukkan hasil yang berbeda-beda maka peneliti tertarik untuk meneliti tentang "Faktor-

\section{Faktor yang Mempengaruhi Struktur Modal".}

Berdasarkan latar belakang yang telah diuraikan diatas, maka rumusan masalah dalam penelitian ini diantaranya (1) Apakah Current Ratio berpengaruh terhadap Struktur Modal pada perusahaan makanan dan minuman yang terdaftar di BEl? (2) Apakah Return On Asset berpengaruh terhadap Struktur Modal pada perusahaan makanan dan minuman yang terdaftar di BEl? (3) Apakah Struktur Aset berpengaruh terhadap Struktur Modal pada perusahaan makanan dan minuman yang terdaftar di BEl? (4) Apakah Ukuran Perusahaan berpengaruh terhadap Struktur Modal pada perusahaan makanan dan minuman yang terdaftar di BEI? (5) Apakah Pertumbuhan Penjualan berpengaruh terhadap Struktur Modal pada perusahaan makanan dan minuman yang terdaftar di BEI?

Tujuan Penelitian ini adalah (1) Untuk menguji dan menganalisis pengaruh Current Ratio terhadap Struktur Modal pada perusahaan makanan dan minuman yang terdaftar di BEI. (2) 
Untuk menguji dan menganalisis pengaruh Return On Asset terhadap Struktur Modal pada perusahaan makanan dan minuman yang terdaftar di BEI. (3) Untuk menguji dan menganalisis pengaruh Struktur Aset terhadap Struktur Modal pada perusahaan makanan dan minuman yang terdaftar di BEl. (4) Untuk menguji dan menganalisis pengaruh Ukuran Perusahaan terhadap Struktur Modal pada perusahaan makanan dan minuman yang terdaftar di BEI. (5) Untuk menguji dan menganalisis pengaruh Pertumbuhan Penjualan terhadap Struktur Modal pada perusahaan makanan dan minuman yang terdaftar di BEI.

Manfaat dari penelitian adalah (1) bagi akademis, diharapkan dapat digunakan sebagai bahan referensi bagi peneliti selanjutnya untuk meneliti tentang faktor - faktor yang mempengaruhi struktur modal dengan sudut pandang yang berbeda. Serta sebagai bahan informasi untuk penelitian selanjutnya dibidang akuntansi keuangan dimasa yang akan datang. (2) Manfaat bagi praktisi, sebagai bahan pertimbangan bagi manajemen perusahaan dalam pengambilan keputusan yang berkaitan dengan struktur modal mengenai besarnya modal yang akan digunakan perusahaan dan dapat sebagai bahan pertimbangan bagi investor dalam memutuskan untuk menanamkan modalnya.

\section{Kajian Literatur}

\subsection{Pecking Order Theory}

Pecking Order Theory menjelaskan mengapa perusahaan - perusahaan yang profitable umumnya meminjam dana dalam jumlah yang sedikit. Menurut Fahmi (2012: 194), pecking order theory merupakan suatu kebijakan yang ditempuh oleh suatu perusahaan untuk mencari tambahan dana dengan cara menjual aset yang dimilikinya.

\subsection{Struktur Modal}

Menurut Horne dan Wachowicz (2007: 232), struktur modal adalah bauran (proporsi), pembiayaan jangka panjang permanen perusahaan yang diwakili oleh utang, saham prefern, dan ekuitas saham biasa. Oleh karena itu keputusan pendanaan merupakan salah satu pilar dalam manajemen keuangan. Keputusan pendanaan, terkait dengan penentuan besarnya kebutuhan dana, dari mana asal dana, jumlah dana dan komposisi dana. Menurut Horne dan Wachowicz (2007) untuk mengukur DER rumusnya:

$$
\text { DER }=\underline{\text { Total Utang }}
$$




\subsection{Current Ratio}

Menurut Kasmir (2014:134), Current Ratio merupakan rasio lancar untuk mengukur kemampuan perusahaan membayar kewajiban jangka pendek atau utang yang segera jatuh tempo pada saat ditagih secara keseluruhan. Dengan kata lain, seberapa banyak aktiva lancar yang tersedia untuk menutupi kewajiban jangka pendek yang segera jatuh tempo. Rasio lancar dapat pula dikatakan sebagai bentuk untuk mengukur tingkat keamanan (margin of safety) suatu perusahaan. Ketika penggunaan modal sendiri lebih tinggi daripada penggunaan hutang, maka perusahaan dapat memenuhi kewajibannya. Hal ini dapat menimbulkan tingkat kepercayaan para kreditur terhadap perusahaan. Menurut Hery (2015:180) rumus menghitung current ratio yaitu :

$$
\begin{aligned}
& \text { Current Ratio }=\underline{\text { Aset Lancar }} \\
& \text { Kewajiban Lancar }
\end{aligned}
$$

\subsection{Return On Asset}

Menurut Agnes (2005:18) Return On Asset adalah rasio yang digunakan untuk mengukur kemampuan manajemen perusahaan dalam memperoleh keuntungan secara keseluruhan. Semakin besar ROA suatu perusahaan, semakin besar pula tingkat keuntungan yang dicapai perusahaan dan semakin baik pula posisi perusahaan tersebut dari segi penggunaan asset. Menurut Hery (2015:228) rumus menghitung Return On Asset sebagai berikut :

$$
\text { ROA }=\frac{\text { Laba Bersih Setelah Pajak }}{\text { Total Aset }} \times 100 \%
$$

\subsection{Struktur Aset}

Menurut Brigham dan Houston (2011), struktur aset adalah perimbangan atau perbandingan antara aset tetap dan total aset. Perusahaan yang mempunyai aset tinggi cenderung akan lebih mudah mendapatkan hutang dibandingkan dengan perusahaan yang mempunyai aset yang kecil karena dengan aset yang tinggi dapat dijadikan jaminan dalam membayar hutang perusahaan. Lim (2012), menyatakan bahwa perusahaan dengan proporsi aset tetap yang tinggi memiliki kemampuan yang lebih besar untuk melunasi utangnya, sehingga memiliki lebih banyak kesempatan untuk memperoleh utang. Menurut Weston dan Brigham (2008) struktur aset dapat diukur dengan : 


\section{Struktur Aset $=\underline{\text { Total Aset Tetap }} \times 100 \%$ \\ Total Aset}

\subsection{Ukuran Perusahaan}

Menurut Suwito dan Arleen (2005), ukuran perusahaan adalah suatu skala yang dapat mengklasifikasikan perusahaan menjadi perusahaan besar dan kecil menurut berbagai cara seperti total aktiva atau total asset perusahaan, nilai pasar saham, rata-rata tingkat penjualan, dan jumlah penjualan. Semakin besar ukuran suatu perusahaan, maka kecenderungan menggunakan modal asing juga semakin besar. Hal ini disebabkan karena perusahaan besar membutuhkan dana yang besar pula untuk menunjang operasionalnya. Menurut Brigham dan Houston (2010), ukuran perusahaan dapat dirumuskan :

$$
\text { Size }=\operatorname{Ln}(\text { Total Aset) }
$$

\subsection{Pertumbuhan Penjualan}

Menurut Kesuma (2009), menyatakan bahwa sales growth adalah kenaikan jumlah penjualan dari tahun ke tahun atau dari waktu ke waktu. Pertumbuhan penjualan yang tinggi maka akan mencerminkan pendapatan perusahaan yang juga meningkat. Laju pertumbuhan suatu perusahaan akan mempengaruhi kemampuan mempertahankan keuntungan alam menandai kesempatan yang akan datang. Pertumbuhan penjualan tinggi maka mencerminkan pendapatan meningkat sehingga beban pajak meningkat. Pertumbuhan penjualan dapat dilihat dari perubahan penjualan tahun sebelum dan tahun periode selanjutnya. Menurut Harahap (2016) pertumbuhan penjualan dapat dirumuskan sebagai berikut :

\section{Pertumbuhan Penjualan $=\underline{\text { Penjualan }(\mathrm{t})-\text { Penjualan }(\mathrm{t}-1)} \times 100 \%$}

$$
\text { Penjualan (t-1) }
$$

\subsection{Kerangka Pemikiran}

Kerangka berpikir merupakan model konseptual tentang bagaimana teori berhubungan dengan berbagai faktor yang telah diindentifikasi sebagai masalah, menurut (Sugiyono, 2012). Konsep yang menghubungkan variabel independen dengan variabel dependen dengan tujuan agar dapat memberikan pengaruh yang positif. Berdasarkan konsep dasar dan hipotesis yang diajukan dalam penelitian ini, dikembangkan dengan model sebagai berikut : 
Gambar 1. Kerangka Berpikir

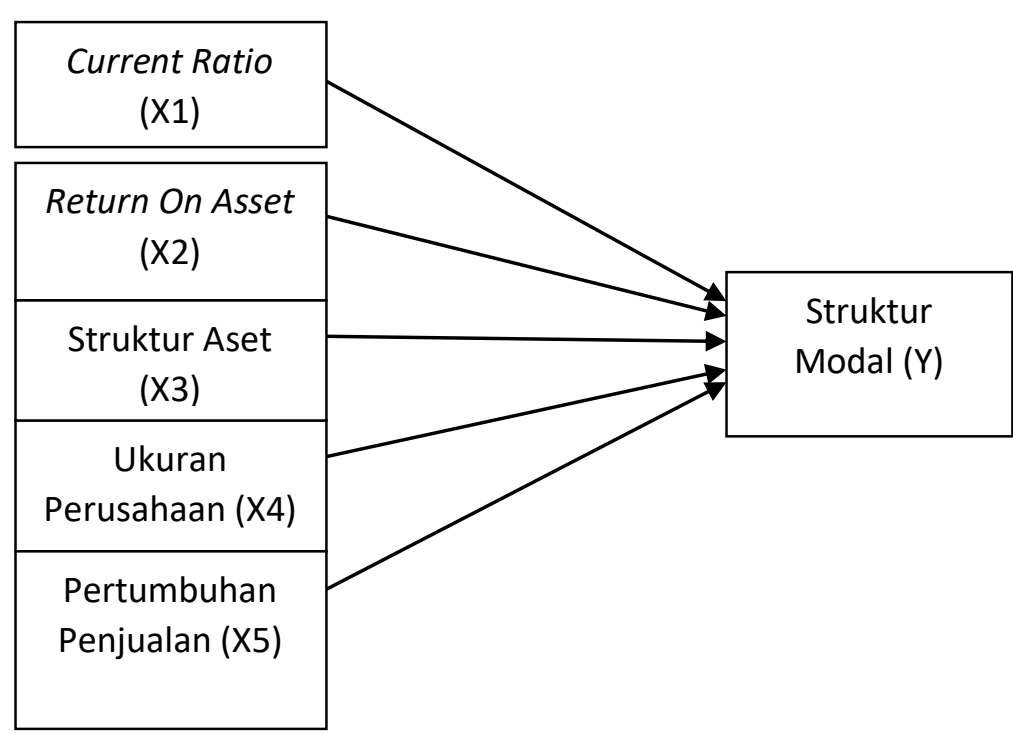

\subsubsection{Pengaruh Current Ratio terhadap Struktur Modal}

Current Ratio dapat digunakan untuk mengukur kemampuan suatu perusahaan dalam melunasi kewajiban-kewajiban jangka pendeknya, dimana bisa diketahui sampai seberapa jauh sebenarnya jumlah aktiva lancar perusahaan bisa menjamin utang lancarnya. Sunhaji (2019) menunjukkan bahwa Current Ratio berpengaruh terhadap Struktur Modal. Berdasarkan uraian diatas, maka hipotesis yang dibangun dalam penelitian ini adalah:

H1: Current Ratio berpengaruh terhadap Struktur Modal

\subsubsection{Pengaruh Return On Asset terhadap Struktur Modal}

Semakin besar Return On Asset suatu perusahaan, semakin besar pula tingkat keuntungan yang dicapai perusahaan dan semakin baik pula posisi perusahaan tersebut dari segi penggunaan asset. Dikarenakan perusahaan akan lebih menggunakan dana internalnya terlebih dahulu. Lina dan Afriza (2018) menunjukkan bahwa Return On Asset berpengaruh terhadap Struktur Modal. Berdasarkan uraian diatas, maka hipotesis yang dibangun dalam penelitian ini adalah :

H2: Return On Asset berpengaruh terhadap Struktur Modal 


\subsubsection{Pengaruh Struktur Aset terhadap Struktur Modal}

Perusahaan yang memiliki banyak aset tetap menunjukkan bahwa perusahaan tersebut memiliki nilai likuiditas yang tinggi sehingga kreditur dapat menerima kembali dana mereka apabila perusahaan dilikuidasi. Sahabuddin (2017) menunjukkan bahwa Struktur Aset berpengaruh terhadap Struktur Modal.Berdasarkan uraian diatas, maka hipotesis yang dibangun dalam penelitian ini adalah:

H3: Struktur Modal berpengaruh terhadap Struktur Modal

\subsubsection{Pengaruh Ukuran Perusahaan terhadap Struktur Modal}

Perusahaan dengan skala besar cenderung akan menggunakan dana eksternal yang berasal dari utang dengan tujuan untuk kegiatan ekspansi perusahaan. Devi et al., (2017) menunjukkan bahwa Ukuran Perusahaan berpengaruh terhadap Struktur Modal. Berdasarkan uraian diatas, maka hipotesis yang dibangun dalam penelitian ini adalah:

H4: Ukuran Perusahaan berpengaruh terhadap Struktur Modal.

\subsubsection{Pengaruh Pertumbuhan Penjualan terhadap Struktur Modal}

Pertumbuhan penjualan perusahaan dapat mencerminkan keberhasilan investor periode masa lalu dan dapat dijadikan prediksi pertumbuhan dimasa yang akan datang. Harina (2018) menunjukkan bahwa Pertumbuhan Penjualan berpengaruh negatif terhadap Struktur Modal. Berdasarkan uraian diatas, maka hipotesis yang dibangun dalam penelitian ini adalah:

H5: Pertumbuhan Penjualan berpengaruh terhadap Struktur Modal

\section{Metode Penelitian}

Jenis penelitian yang dilakukan adalah penelitian kausal komparatif. Menurut Kuncoro (2003) penelitian kausal komparatif adalah penelitian yang menunjukkan hubungan variabel dependen dengan variabel independen, disamping mengukur kekuatan hubungannya. Jenis penelitian yang digunakan berupa penelitian kuantitatif yang menggunakan angka-angka dan dengan perhitungan statistik. Penelitian ini terdiri dari 2 jenis variabel yaitu 1) Variabel Dependen yaitu Struktur Modal 2) Variabel Independen yaitu CR, ROA, Struktur Aset, Ukuran Perusahaan, Petumbuhan Penjualan. Data yang digunakan data sekunder, dengan populasi perusahaan 
makanan minuman yang terdaftar di BEI tahun 2015 - 2018. Pengambilan sampel menggunakan metode purposive sampling yaitu sampel diambil berdasarkan kriteria tertentu.

Adapun kriteria dalam penelitian ini adalah : 1) Perusahaan makanan dan minuman yang terdaftar di BEI 2015 - 2018 2) Perusahaan makanan dan minuman yang telah melakukan IPO sebelum periode pengamatan 3) Perusahaan makanan dan minuman yang tidak mengalami kerugian 4) Data Outlier. Instrumen penelitian berupa dokumentasi laporan keuangan perusahaan makanan dan minuman yang terdaftar di Bursa Efek Indonesia periode 2015 - 2018. Alat analisis yang digunakan yaitu analisis regresi linear berganda.

\section{Hasil dan Pembahasan}

\subsection{Deskripsi Umum Data Penelitian}

Adapun kriteria pengambilan sampel adalah sebagai berikut :

Tabel 1

Pengambilan Sampel

\begin{tabular}{llc}
\hline No & \multicolumn{1}{c}{ Keterangan } & Jumlah \\
\hline 1. & Perusahaan makanan dan minuman yang terdaftar di Bursa Efek & 26 \\
& Indonesia $2015-2018$ & \\
\hline 2. & Perusahaan yang melakukan IPO sebelum periode pengamatan & $(7)$ \\
\hline 3. & Perusahaan makanan minuman yang mengalami kerugian & $(9)$ \\
\hline 4. & Data Outlier & $(2)$ \\
\hline 5. & Perusahaan yang menjadi sampel & 10 \\
\hline & Jumlah data yang diolah (4 tahun) & 40 \\
\hline
\end{tabular}

4.2. Uji Asumsi Klasik

\subsubsection{Uji Normalitas}

Tabel 2

Uji Normalitas

\begin{tabular}{cccc}
\hline Variabel & Sig & Standar & Keterangan \\
\hline $\mathrm{Ha}$ & 0,914 & $>0,05$ & Terdistribusi Normal \\
\hline
\end{tabular}

Berdasarkan hasil uji normalitas dengan menggunkan One-Sampel Kolmogrov-Sminorv Test, dapat dilihat nilai signifikannya adalah 0,914 > 0,05 maka hasilnya adalah normal. 


\subsubsection{Uji Multikolinearitas}

Berdasarkan tabel di bawah ini dapat diketahui bahwa hasil pengujian semua variabel independen baik Current Ratio, Return On Asset, Struktur Aset, Ukuran Perusahaan dan Pertumbuhan Penjualan memiliki nilai tolerance $>0,1$ dan VIF $<10$. Hasil penelitian ini dapat disimpulkan bahwa tidak terjadi multikolinearitas.

Tabel 3

Uji Multikolinearitas

\begin{tabular}{llllll}
\hline \multicolumn{1}{c}{ Variabel } & $\begin{array}{l}\text { Toler } \\
\text { ance }\end{array}$ & Syarat & VIF & Syarat & Keputusan \\
\hline $\mathrm{CR}$ & 0,896 & $>0,1$ & 1,116 & $<10$ & Tidak terjadi Multikolonieritas \\
\hline $\mathrm{ROA}$ & 0,964 & $>0,1$ & 1,037 & $<10$ & Tidak terjadi Multikolonieritas \\
\hline Struktur Aset & 0,848 & $>0,1$ & 1,179 & $<10$ & Tidak terjadi Multikolonieritas \\
\hline Ukuran Perusahaan & 0,817 & $>0,1$ & 1,225 & $<10$ & Tidak terjadi Multikolonieritas \\
\hline $\begin{array}{l}\text { Pertumbuhan } \\
\text { Penjualan }\end{array}$ & 0,922 & $>0,1$ & 1,085 & $<10$ & Tidak terjadi Multikolonieritas \\
\hline
\end{tabular}

4.2.3. Uji Heterokdastisitas

Tabel 4

Uji Heterokdastisitas

\begin{tabular}{lccc}
\hline \multicolumn{1}{c}{ Variabel } & Sig & Standar & Keterangan \\
\hline CR & 0,952 & $>0,05$ & Tidak terjadi heteroskedastisitas \\
\hline ROA & 0,811 & $>0,05$ & Tidak terjadi heteroskedastisitas \\
\hline Struktur Aset & 0,687 & $>0,05$ & Tidak terjadi heteroskedastisitas \\
\hline Ukuran Perusahaan & 0,695 & $>0,05$ & Tidak terjadi heteroskedastisitas \\
\hline Pertumbuhan Penjualan & 0,844 & $>0,05$ & Tidak terjadi heteroskedastisitas \\
\hline
\end{tabular}

Berdasarkan pengujian yang telah dilakukan, pada tabel diatas menunjukkan tidak ada satupun variabel independen yang signifikansi secara statistik memengaruhi variabel dependen. $\mathrm{Hal}$ ini terlihat dari probabilitas signifikasinya di atas tingkat kepercayaan 0,05\% atau 5\%. Jadi dapat disimpulkan model regresi bebas heteroskedastisitas, maka HO diterima (Tidak terjadi heteroskedastisitas).

\subsubsection{Uji Autokorelasi}

Berdasrkan hasil uji autokorelasi, dapat dilihat bahwa nilai signifikasi sebesar 
$-0,873$ > dari 0,05 maka dapat dismpulkan bahwa tidak terjadi gejala autokorelasi.

Tabel 5

Uji Run Test

\begin{tabular}{ccc}
\hline Sig & Syarat & Kesimpulan \\
\hline 0,873 & $>0,05$ & Tidak terjadi Autokorelasi \\
\hline
\end{tabular}

\subsection{Model Regresi}

Berdasarkan tabel 6, maka persamaan model regresi berbentuk:

$Y=a+\beta_{1} X_{1}+\beta_{2} X_{2}+\beta_{3} X_{3}-\beta_{4} X_{4}+\beta_{5} X_{5}+e$

$Y=-0,181+0,754 X_{1}+0,754 X_{2}+0,494 X_{3}-0,092 X_{4}+0,405 X_{5}+e$

Berdasarkan tabel 6 model layak untuk diuji.

Tabel 6

Model Regresi

\begin{tabular}{ll}
\hline \multicolumn{1}{c}{ Model } & B \\
\hline Constant & $-0,181$ \\
\hline CR & 0,754 \\
\hline ROA & 0,754 \\
\hline Struktur Aset & 0,494 \\
\hline Ukuran Perusahaan & $-0,092$ \\
\hline Pertumbuhan Penjualan & 0,405 \\
\hline
\end{tabular}

4.4. Uji Kelayakan Model (Uji F)

Tabel 7

Uji F

\begin{tabular}{cccccc}
\hline Hipotesis & Fhitung & Ftabel & Sig & Syarat & Keputusan \\
\hline $\mathrm{Ha}$ & 5,487 & 2,650 & 0,001 & $<0,05$ & Model Layak \\
\hline
\end{tabular}

Berdasarkan tabel diatas, nilai Fhitung adalah 5,487 dan signifikansi 0,001. F tabel dapat dilihat dari tabel $F$ pada tingkat signifikansi 0,05 dengan df (jumlah variabel -1 ) $=5-1=4$ dan df $2=\mathrm{n}-\mathrm{k}-1 ;$ dimana $\mathrm{n}$ adalah jumlah data, $\mathrm{k}$ adalah jumlah variabel independen, df $2=40-5$ $-1=34$. Hasil yang diperoleh untuk $F$ tabel df $1=2$ dan df $2=40$ adalah 2,650.

Hasil pengujian menunukkan bahwa nilai $F$ hitung $>F$ tabel $(5,487>2,650)$ dan signifikansi $<0,05(0,001<0,05)$, sehingga dapat disimpulkan bahwa $\mathrm{HO}$ ditolak sedangkan Ha diterimsa atau model layak. Hasil pengujian menunjukkan bahwa Ha diterima, artinya CR (X1), ROA (X2), 
Struktur Aset, Ukuran Perusahaan dan Pertumbuhan Penjualan secara simultan berpengaruh terhadap Struktur Modal (Y).

\subsection{Uji Hipotesis}

\section{Tabel 8}

Uji Hipotesis

\begin{tabular}{lccccc}
\hline \multicolumn{1}{c}{ Hipotesis } & Thitung & Ttabel & Sig & Syarat & Hasil \\
\hline H1 (CR) & $-3,304$ & $-1,691$ & 0,002 & $<0,05$ & Diterima \\
\hline H2 (ROA) & 1,425 & 1,691 & 0,163 & $<0,05$ & Ditolak \\
\hline H3 (Struktur Aset) & 1,384 & 1,691 & 0,176 & $<0,05$ & Ditolak \\
\hline H4 (Ukuran & $-2,241$ & $-1,691$ & 0,032 & $<0,05$ & Diterima \\
Perusahaan) & & & & & \\
\hline H5 (Pertumbuhan & 0,507 & 1,691 & 0,615 & $<0,05$ & Ditolak \\
\begin{tabular}{l} 
Penjualan) \\
\hline
\end{tabular} & & & & & \\
\hline
\end{tabular}

1. Current Ratio berpengaruh terhadap Struktur Modal

Berdasarkan tabel uji regresi linear berganda, diperoleh nilai koefisien regresi sebesar 3,304 dengan nilai Ttabel -1,691 sehingga Thitung > Ttabel. Dengan signifikansi sebesar $0,002<0,05$. Maka dapat disimpulkan bahwa Current Ratio berpengaruh terhadap struktur modal, sehingga hipotesis pertama diterima.

2. Return On Asset tidak berpengaruh terhadap Struktur Modal

Berdasarkan tabel uji regresi linear berganda, diperoleh nilai koefisien regresi sebesar 1,425 dengan nilai Ttabel -1,691 sehingga Thitung > Ttabel. Dengan signifikansi sebesar $0,163<0,05$. Maka dapat disimpulkan bahwa Return On Asset tidak berpengaruh terhadap struktur modal, sehingga hipotesis kedua ditolak.

3. Struktur Aset tidak berpengaruh terhadap Struktur Modal

Berdasarkan tabel uji regresi linear berganda, diperoleh nilai koefisien regresi sebesar 1,384 dengan nilai Ttabel 1,691 sehingga Thitung > Ttabel. Dengan signifikansi sebesar $0,176<0,05$. Maka dapat disimpulkan bahwa Struktur Aset tidak berpengaruh terhadap struktur modal, sehingga hipotesis ketiga ditolak.

4. Ukuran Perusahaan berpengaruh terhadap Struktur Modal

Berdasarkan tabel uji regresi linear berganda, diperoleh nilai koefisien regresi sebesar 2,241 dengan nilai Ttabel -1,691 sehingga Thitung > Ttabel. Dengan signifikansi sebesar $0,032<0,05$. Maka dapat disimpulkan bahwa Ukuran Perusahaan berpengaruh terhadap struktur modal, sehingga hipotesis keempat diterima.

5. Pertumbuhan Penjualan tidak berpengaruh terhadap Struktur Modal 
Berdasarkan tabel uji regresi linear berganda, diperoleh nilai koefisien regresi sebesar 0,507 dengan nilai Ttabel 1,691 sehingga Thitung > Ttabel. Dengan signifikansi sebesar 0,615 $<0,05$. Maka dapat disimpulkan bahwa Pertumbuhan Penjualan tidak berpengaruh terhadap struktur modal, sehingga hipotesis kelima ditolak.

\subsection{Uji Koefisien Determinasi}

Berdasarkan tabel 8 dapat dilihat besarnya nilai Adjusted $R$ Square adalah 0,365\% atau sebesar $36,5 \%$. Hal ini berarti $36,5 \%$ dari $Y$, dapat dijelaskan oleh variabel - variabel independen current ratio, return on asset, struktur aset, ukuran perusahaan, dan pertumbuhan penjualan. Sedangkan sisanya sebesar $63,5 \%$ (100\%-36,5\%) dijelaskan oleh variabel - variabel yang lain selain variabel penjelas atau variabel independen diluar model peneliti ini.

Tabel 9

Uji Koefisien Determinasi

\begin{tabular}{cc}
\hline Adjusted R Square & Kesimpulan \\
\hline 0,365 & Berpengaruh sebesar $36,5 \%$ \\
\hline
\end{tabular}

\subsection{Pembahasan}

\subsubsection{Pengaruh Current Ratio terhadap Struktur Modal}

Hipotesis pertama dalam penelitian ini yaitu current ratio berpengaruh terhadap struktur modal. Berdasarkan pengujian yang telah dilakukan diperoleh hasil koefisien sebesar -3,304 dengan signifikansi sebesar 0,002 yang artinya lebih kecil dari 0,05. Hal ini menunjukkan bahwa current ratio berpengaruh terhadap struktur modal. Oleh karena itu, $\mathrm{H} 1$ yang menyatakan bahwa current ratio berpengaruh signifikan terhadap struktur modal.

Semakin tingginya rasio yang ditawarkan maka semakin besar pula peluang kreditor untuk mendapatkan pelunasan utang - utang dari perusahaan. Perusahaan dengan tingkat current ratio yang tinggi menunjukkan perusahaan tersebut mempunyai cukup banyak dana yang digunkan untuk operasi perusahaan. Dengan semakin tingginya nilai current ratio, maka semakin rendah pula nilai struktur modal. Dalam Pecking Order Theory, perusahaan dengan current ratio yang tinggi cenderung akan menggunakan dana interlnya terlebih dahulu dibanding dari dana eksternalnya. Hasil penelitian ini sesuai dengan Novianti (2015), Wardiansyah (2016), tetapi hasil penelitian berbeda dengan (Infantri, 2015). 


\subsubsection{Pengaruh Return On Asset terhadap Struktur Modal}

Hipotesis kedua dalam penelitian ini yaitu return on asset tidak berpengaruh terhadap struktur modal. Berdasarkan pengujian yang telah dilakukan diperoleh hasil koefisien sebesar 1,425 dengan signifikansi sebesar 0,163 yang artinya lebih besar dari 0,05. Hal ini menunjukkan bahwa return on asset tidak berpengaruh terhadap struktur modal. Oleh karena itu, $\mathrm{H} 2$ yang menyatakan bahwa return on asset tidak berpengaruh signifikan terhadap struktur modal.

Hal ini disebabkan karena perusahaan mengalami penurunan dalam penjualan sehingga mengakibatkan pendapatan menurun pula. Sehingga perusahaan akan cenderung menggunakan dana eksternal untuk menunjang aktivitas operasi pendanaan perusahaan. Hasil penelitian ini sesuai dengan Wardiansyah (2016), tetapi hasil berbeda dengan Lina dan Afriza (2018).

\subsubsection{Pengaruh Struktur Aset terhadap Struktur Modal}

Hipotesis kedua dalam penelitian ini yaitu return on asset tidak berpengaruh terhadap struktur modal. Berdasarkan pengujian yang telah dilakukan diperoleh hasil koefisien sebesar 1,384 dengan signifikansi sebesar 0,176 yang artinya lebih besar dari 0,05. Hal ini menunjukkan bahwa struktur aset tidak berpengaruh terhadap struktur modal. Oleh karena itu, H3 yang menyatakan bahwa struktur aset tidak berpengaruh signifikan terhadap struktur modal.

Menunjukkan bahwa struktur aset perusahaan mengalami penurunan dikarenakan mempunyai aset tetap yang lebih kecil dibandingkan total aset yang dimiliki perusahaan, maka menjadikan perusahaan kurang dapat memenuhi kebutuhan dari modal sendiri. Sehingga perusahaan dengan struktur aset yang rendah kurang dapat menjamin hutang perusahaan. Hasil penelitian ini sesuai dengan Sari et al., (2018), tetapi hasil berbeda dengan Jusrizal (2017), Denziana dan Yunggo (2017), Septiani dan Suryana (2018).

\subsubsection{Pengaruh Ukuran Perusahaan terhadap Struktur Modal}

Hipotesis keempat dalam penelitian ini yaitu ukuran perusahaan berpengaruh terhadap struktur modal. Berdasarkan pengujian yang telah dilakukan diperoleh hasil koefisien sebesar 2,241 dengan signifikansi sebesar 0,032 yang artinya lebih kecil dari 0,05. Hal ini menunjukkan bahwa ukuran perusahaan berpengaruh terhadap struktur modal. Oleh karena itu, H4 yang menyatakan bahwa ukuran perusahaan berpengaruh signifikan terhadap struktur modal.

Menunjukkan bahwa besar kecilnya suatu perusahaan (ukuran perusahaan) sangat berpengaruh terhadap struktur modal. Perusahaan yang besar akan membutuhkan dana yang besar untuk menunjang operasi pendanaan perusahaan, maka perusahaan akan memakai utang 
yang lebih banyak. Sedangkan perusahaan yang kecil memiliki resiko kebangkrutan yang lebih besar sehingga akan sulit mendapatkan pinjaman dana dari eksternal, dengan begitu perusahaan sebisa mungkin menggunakan dana internalnya dengan baik untuk mengelola aktivitas perusahaan. Hasil penelitian ini sesuai dengan Amalia (2016), Denziana dan Yunggo (2017), Ratri dan Christianti (2017). Septiani dan Suaryana (2018). tetapi berbeda dengan Lina dan Afriza (2018).

\subsubsection{Pengaruh Pertumbuhan Penjualan terhadap Struktur Modal}

Hipotesis kedua dalam penelitian ini yaitu pertumbuhan penjualan tidak berpengaruh terhadap struktur modal. Berdasarkan pengujian yang telah dilakukan diperoleh hasil koefisien sebesar 0,507 dengan signifikansi sebesar 0,615 yang artinya lebih besar dari 0,05. Hal ini menunjukkan bahwa pertumbuhan penjualan tidak berpengaruh terhadap struktur modal. Oleh karena itu, H5 yang menyatakan bahwa pertumbuhan penjualan tidak berpengaruh signifikan terhadap struktur modal.

Hal ini disebabkan pertumbuhan penjualan mengalami kenaikan yang kecil dari tahun sebelumnya. Perusahaan dengan tingkat pendapatkan yang rendah maka struktur modal perusahaan juga rendah. Sehingga perusahaan kurang dapat melakukan pembiayaan dari modal sendiri perusahaan. Hasil penelitian ini sesuai dengan Hartati dan Mukhibad (2018), tetapi berbeda dengan Ratri dan Christianti (2017), Lina dan Afriza (2018), Sunhaji (2019).

\section{Kesimpulan}

Penelitian ini bertujuan untuk menguji dan menganalisis pengaruh current ratio, return on asset, struktur aset, ukuran perusahaan dan pertumbuhan penjualan terhadap struktur modal pada perusahaan makanan dan minuman yang terdaftar di Bursa Efek Indonesia. Berdasarkan hasil analisis yang telah diuji menggunakan analisis regresi linear berganda, diperoleh hasil bahwa current ratio dan ukuran perusahaan berpengaruh terhadap struktur modal, sedangkan return on asset, struktur aset dan pertumbuhan penjualan tidak berpengaruh terhadap struktur modal.

Penelitian ini memiliki beberapa keterbatasan, yaitu : (1) Penelitian ini hanya menggunakan lima variabel yaitu, current ratio, return on asset, struktur aset, ukuran perusahaan dan pertumbuhan penjualan. (2) Penelitian ini hanya menggunakan jangka waktu 4 tahun yaitu 2015 - 2018, sehingga hasilnya kurang mencerminkan kondisi perusahaan dalam jangka panjang. (3) Penelitian hanya terbatas menggunakan sampel perusahaan makanan dan minuman sehingga kurang mewakili seluruh sektor yang terdaftar di Bursa Efek Indonesia. 
Berdasarkan keterbatasan tersebut, berikut saran untuk penelitian selanjutnya yaitu: (1) Pada penelitian selanjutnya, sebaiknya menambahkan variabel lain dan variabel moderasi dalam penelitian struktur modal selain variabel independen yang sudah digunakan dalam penelitian ini sehingga dapat menunjukkan hasil yang lebih variatif. Contoh variabel lain yang mungkin dapat mempengaruhi struktur modal diantaranya : Growth Opportunity, Dividend Policy, Kepemilikan Manajerial, Resiko Bisnis, Pertumbuhan Aktiva. (2) Peneliti selanjutnya, sebaiknya menambah periode pengamatan dengan jangka waktu lebih lama. Sehingga dapat mencerminkan keadaan perusahaan dimasa yang akan datang, (3) Untuk peneliti selanjutnya, sebaiknya memambah sampel penelitian tidak hanya perusahaan makanan dan minuman saja sehingga dapat mecerminkan keadaan yang sebenarnya dalam perusahaan sektor Food and Beverage.

\section{Daftar Pustaka}

Agnes, S. 2005. Analisis Kinerja Keuangan dan Perencanaan Keuangan. Jakarta: PT. Gramedia Pustaka Utama.

Brigham, E., dan J. Houston. 2010. Manajemen Keuangan. Edisi Kesebelas. Jakarta: Salemba Empat.

Brigham, E., dan Houston, J. 2011. Dasar-Dasar Manajemen Keuangan. Edisi Kesepuluh. Jakarta: Salemba Empat.

Denziana, A., dan Yunggo, E. D. 2017. Pengaruh Profitabilitas, Struktur Aktiva, Dan Ukuran Perusahaan Terhadap Strutur Modal Pada Perusahaan Real Estate Ad Property Yang Terdaftar Di Bursa Efek Indonesia Tahun 2015. Jurnal Akuntansi \& Keuangan 8(1): 5167.

Devi, N. N., N.G. Sulindawati, dan M.A. Wahyuni. 2017. Pengaruh Struktur Aktiva, Profitabilitas, Ukuran Perusahaan, Likuiditas, Dan Kepemilikan Manajerial Terhadap Struktur Modal Perusahaan ()Studi Empiris Pada Perusahaan ManufakturYang Terdaftar Di Bursa Efek Indonesia Periode 2013-2015). Jurnal IImiah Mahasiswa Akuntansi 7(1).

Effendi, M., dan Nugraha. 2018. Return On Assets, Likuiditas dan Ukuran Perusahaan Terhadap Struktur Modal. Jurnal Ekonomi dan Bisnis 2(1): 44 - 54.

Fahmi, I. 2012. Pengantar Manajemen Keuangan. Bandung: Alfabeta.

Ghasemi, M., dan Razak, N. H. 2016. The Impact of Liquidity on the Capital Structure : Evidence from Malaysia. International Journal of Economics and Finance 8(10): 130-139.

Harina, E. T. 2018. Pengaruh Profitabilitas,Pertumbuhan Penjualan, Struktur Aktiva Dan Ukuran Perusahaan Terhadap Struktur Modal Pada Perusahaan Property Dan Real Estate Yang Terdaftar Di Bursa Efek Indonesia. Jurnal EcoGen 1(1): 87-96.

Hartati, M. S., dan H. Mukhibad. 2018. The Influence of Profitability, Liquidity, Business Risk, Firm Size, and Sales Growth in The Property and Real Estate Companies Listed in the Idx During 2013-2016. Accounting Analysis Journal 7(2):103-110.

Hery. 2015. Analisis Kinerja Manajemen The Best Financial Analysis Menilai Kinerja Manajemen Berdasarkan Rasio Keuangan. Jakarta: PT.Grasindo.

Horne, J. V., dan J. Wachowicz. 2007. Prinsip -Prinsip Manajemen Keuangan. Edisi Kedua Belas. Jakarta: Salemba Empat.

Jusrizal. 2017. Fakor-faktor yang mempengaruhi Struktur Modal . PROFITA 10(3): 373-387.

Kasmir. 2014. Analisis Laporan Keuangan.. Jakarta: PT Raja Grafindo Persada.

Kesuma, A. 2009. Analisis Faktor Yang Mempengaruhi Struktu Modal Serta Pengaruhnya Terhadap Harga Saham Perusahaan Real Estate yang Go Public di Bursa Efek Indonesia. Jurnal Manajemen dan Kewirausahaan 11(1): 38-45.

Kuncoro, M. 2003. Metode Riset untuk Bisnis \& Ekonomi. Jakarta: Erlangga. 
Lim, T.C. 2012. Determinants of Capital Structure Empirical Evidence from Financial Services Listed Firm in China. International Journal of Economics and Finance 4(3): 191-203.

Lina, dan A. Afriza. 2018. Pengaruh Return On Asset, Current Ratio, Size dan Growth Terhadap Struktur Modal Pada Perusahaan Manufaktur Yang Terdaftar di Bursa Efek Indonesia Periode 2013 - 2015. . Jurnal Riset Akuntansi Going Concern 13(4), 893 - 902.

Naray, A. R., dan M. Lisabeth. 2015. Pengaruh Pertumbuhan Penjualan , Stuktur Aktiva Dan Ukuran Penjualan Terhadap Struktur Modal Pada Bank Pemerintah Kategori Buku 4. Jurnal Riset Ekonomi, Manajemen, Bisnis, dan Akuntansi 3(2): 896-907.

Ratri, A. M., dan A. Christianti. 2017. Pengaruh Size, Likuiditas, Profitabilitas, Risiko Bisnis, Dan Pertumbuhan Penjualan Terhadap Struktur Modal Pada Sektor Industri Properti. Jurnal Riset Manajemen dan Bisnis 12(1): 13-24.

Sahabuddin, Z. 2017. Asset Structure Impact on Capital Structure of Capital Market-Listed Firms in Indonesia and Malaysia. Jurnal Keuangan dan Perbankan 21(3): 376-386.

Sari, N. I., K. H. Titisari, dan S. Nurlalela. 2018. The Effect Structure of Assets, Liquidity, Firm Size and Profitability of Capital Structure (Empirical Study on Manufacturing Companies Listed on Indonesia Stock Exchange). Proseding Seminar Nasional Akuntansi 2(1).

Septiani, N. N., dan I. N. Suaryana.2018. Pengaruh Profitabilitas, Ukuran Perusahaan, Struktur Aset, Risiko Bisnis dan Likuiditas pada Struktur Modal . E-Jurnal Akuntansi Universitas Udayana , 22(3): 1682-1710.

Sugiyono. 2012. Metode Penelitian Bisnis. Bandung: Alfabeta.

Sunhaji. 2009. Strategi Pembelajaran, Konsep Dasar, Metode, dan Aplikasi dalam Proses Belajar Mengajar. Yogyakarta: Grafindo Litera Media.

Suwito, E., dan A. Herawaty. 2005. Ukuran Perusahaan, Rasio Profitabilitas Perusahaan, Rasio Leverage Operasi Perusahaan, Net Profit Margin Perusahaan terhadap Tindakan Perataan Laba yang Dilakukan oleh Perusahaan yang Terdaftar di BEJ. Proceeding Simposium Nasional Akuntansi (SNA) VI, Solo. 65-78.

Wardiansyah, F. 2016. Pengaruh Pertumbuhan Aset, Current Ratio, Return On Asset, Risiko Bisnis dan Penghematan Pajak Terhadap Struktur Modal pada Perusahaan Manufaktur Sektor Industri Barang Konsumsi di Bursa Efek Indonesia (BEI) Periode 2010-2014. Jurnal Umrah: 1-22.

Weston, J. F., dan E.F. Brigham.(2008). Dasar-dasar Manajemen Keuangan. Edisi Kedua. Jakarta: Erlangga. 